\title{
THE ROLE OF REASON IN PLATO'S PHILOSOPHY
}

\author{
A Domanski (University of the Witwatersrand)
}

\begin{abstract}
The world of the Platonic teaching is a realm of changelessness for a heart saddened by the spectacle of inevitable change. It is order for a mind perturbed by a nightmare of endless chaos. It is the cosmos of reason, of which one may have a glimpse in anything of beauty ... It is the pattern which the mind of man may come to know ... (Edman 1927: xxxviii)
\end{abstract}

In the Timaeus, Plato speaks of the "perfect and splendid feast of reason". The aim of this article is to follow the call of reason, as it resonates through the dialogues ${ }^{2}$ and elsewhere. That call is strong, yet gentle: it does not rely on force in order to make itself heard. Plato's teacher, Socrates, proclaims his allegiance to reason in these words: "I am and always have been one of those natures who must be guided by reason."

But what is reason? ${ }^{4}$ Our point of departure is a passage in the Laws, where Plato speaks of reason as a "sacred and golden cord". This cord exists in every one of

Timaeus 27c (Jowett 1937b:12).

Recent literature on reason and rationality in Plato includes Desjardins 1990; Frede \& Striker 1996; Dixsout 1999; Miller 1997; Schmid 1998; Hendrix 2000. At the risk of over-burdening the text with direct quotations, I shall wherever possible allow Plato to speak in his own voice (albeit in translation). Two other practices which I adopt in this article should be mentioned here. First, I take the views of the Platonic Socrates for what they really are, namely unilateral statements of principle. In the dialogues these views are dressed up as consensus positions arrived at by Socrates and his interlocutors by a bilateral process of question and answer. But the consensus is seldom genuine: the contribution of the interlocutor is usually no more than a pro-forma affirmation of Socrates' argument. Secondly, I attribute the views of the Platonic Socrates to Plato himself. For this practice there is ample authority: see, for example, Guthrie 1962:107; Field 1967:61-63; Penner 1992:121f; Rowe 1984:1-4.

3 Crito 46b (Jowett 1937a:430).

4 This article may leave some readers with the impression that the term "reason" is the English translation of a single Greek word which Plato uses consistently throughout the dialogues. This is not the case. The passages from Plato considered in this article contain three key words, all of which, following Jowett, I render here as "reason". These words, in transliteration, are logismos, logos and nous. The first of these is used consistently by Plato in the relevant passages of the Republic. The relevant passages of the Timaeus and the Laws employ logos more often than logismos. The word nous occurs in the relevant passages of the Philebus and the Laws. Some translators give different meanings to these three words. What justification is there for rendering them all as "reason" in the present context? First, logismos is derived from logos. There are those who would deny this link, but their case cannot stand: apart from the clear etymological connection between these words, the contexts in which they occur in the passages cited in this article demand a substantial overlap, if not an identity of meaning between them. If further justification be required for the rendering of logos as reason, it is afforded by Suzanne (1996:9): "One of the most important things man has to know about himself is the power and limits of logos, a Greek word which means at the same time speech, definition, rationale and reason, among other things." The decision to render nous as "reason" finds strong support in the tenor of 
us and pulls us in the direction of truth. He enjoins us to grasp this cord and never to let go, but to pull with it against all the other cords within us. These other cords, if left to themselves, pull us in the direction of untruth and ignorance. Here is this key passage ${ }^{5}$ :

[T] hese affections in us are like cords and strings, which pull us different and opposite ways, and to opposite actions; and herein lies the difference between virtue and vice ... [T] here is one among these cords which every man ought to grasp and never let go, but to pull with it against all the rest; and this is the sacred and golden cord of reason, ${ }^{6}$ called by us the common law of the State ${ }^{7}$; there are others which are hard and of iron, but this one is soft because golden; and there are several other kinds. Now we ought always to co-operate with the lead of the best, which is law. For inasmuch as reason is beautiful and gentle and not violent, her rule must needs have ministers in order to help the golden principle in vanquishing the other principles. And ... the individual, attaining to right reason ... should live according to its rule; while the city, receiving the same [right reason] from some god or from one who has knowledge of these things, should embody it in a law to be her guide in her dealings with herself and with other states. In this way, virtue and vice will be more clearly distinguished by us. And when they have become clearer, education and other institutions will in like manner become clearer...

In this passage, Plato shows that law and reason are inseparable. Cicero, an admirer and follower of Plato, was later to echo this principle. Here is Cicero's famous definition of natural law ${ }^{8}$ :

True law is right reason in agreement with Nature; it is of universal application, unchanging and everlasting... We cannot be freed from its obligations by Senate or People, and we need not look outside ourselves for an expounder or interpreter of it. And there will not be different laws at Rome and at Athens, or different laws

the relevant passages (Philebus 28c-e, 30c-e, and Laws 713e-714a) in which this word occurs. These terms logismos, logos and nous are by no means exhaustive: in the dialogues, Plato uses also dianoia (in the Phaedo), logistikon (Republic 605b), and other words to denote "reason".

$5 \quad$ Laws 644d-645c (Jowett 1937b:425-6).

6 Two translators who misrepresent logismos in this passage by rendering it as "calculation" instead of "reason", are Bury (1926:69) and Saunders (1975:74). This rendering is awkward, jarring and entirely at odds with the tenor of the passage. Bury, for example, speaks of the "golden and holy leading-string of "calculation"”. What does this mean?

7 Jowett's use here of the term "common law" has been attacked on the ground that the specialized modern meaning of this term in law is not appropriate in the present context. This criticism is unfounded: one meaning of "common law" today is the body of reasoned judgments of courts of Law. This is surely close to what Plato regards as the counterpart in the state to the faculty of reason in the individual. Less accurate in the context is Saunders' rendering "public law".

$8 \quad$ Cic. De Rep. 3.22.33 (D’Entréves 1952:20-21). See also Plato's injunction in Laws 713e-714a. Plato's influence on Cicero may not have been direct: it may instead have been coloured or perhaps even formed by Cicero's attendance at lectures on ancient Greek philosophy given by Antiochus of Ascalon in Athens in 78-79BC. 
now and in the future, but one eternal and unchangeable law will be valid for all nations and for all times, and there will be one master and one ruler, that is God, over us all, for he is the author of this law, its promulgator and its enforcing judge.

Thus, what is reasonable is lawful, what is unreasonable is not: when reason and law part company, we get law which is not worthy of the name. ${ }^{9}$

What is the place and function of reason in the human soul? Plato gives a full answer to this question in the fourth book of the Republic. There he identifies three key elements in the soul (psuchē). All three are present in every soul, but they manifest to different degrees in different individuals. ${ }^{10}$ They are, first, reason or the rational element (logismos) $)^{11}$; secondly, the element of appetite or desire (epithumia); and thirdly, the element of resolution or spirit (thumos). ${ }^{12}$ As we shall see later, Plato locates reason in the head, spirit in the breast (that is, in the heart), and appetite in the belly. We shall now consider each of these elements in turn.

Plato holds ${ }^{13}$ that, of the three elements in the human soul, reason alone is immortal and separable from the body. Reason, the first and highest of the elements, ought to rule man, having the wisdom and foresight to act for the whole ${ }^{14}$. Plato calls reason the divine element in man. ${ }^{15}$ It is that part of the soul whereby man reflects. ${ }^{16}$ Its sole endeavour is to know the truth. It is the element which gives us understanding. It is that in us which loves knowledge and wisdom. ${ }^{17}$ Reason is the hallmark of the philosopher and rational argument is his special tool. ${ }^{18}$ While this article is in no sense a comparative study, it will already be clear that the Platonic notion of reason, as the divine and immortal element in man, is far removed from our secular modern ideas on the subject.

What of the second element? That part of the soul which feels hunger, thirst, the agitations of sex, the love of money and other desires, Plato calls irrational appetite - an element closely connected with satisfaction and pleasure. ${ }^{19}$ He does not

9 For a recent and striking case in point involving Mother Teresa, the late Nobel Prize winner, see Howard 1996:3-5.

$10 \quad$ Republic; Cornford 1941:129.

See note 4 above.

Or thumoeides : Republic 434-440. The Concise Oxford Dictionary defines "spirited" as "full of spirit, animated, lively, brisk, courageous".

Timaeus 90c; Cornford 1941:130.

Republic 441e. Unless otherwise stated, I rely on the translation of this dialogue in Lee 1987.

15 See, for example, Timaeus 90a-c, Republic 500d. Lee (1987:207) describes reason in more mundane terms as "not only the ability to understand and to think before we act, the faculty of calculation and foresight, but also the ability to make up one's mind, the faculty of decision". The same writer (at 208) refers to this element as the "rational, controlling, authoritative part of the mind".

16 Republic 439d.

17 Republic 580d, 581b.

Republic 582d-e.

Republic 439d, 436a. Lee (1987:207) describes appetite as "bare physical and instinctive craving and as 'the purely instinctive desires in their simplest form'. The same writer (at 208) calls this element simply 'animal instinct"'. 
treat all desires on the same footing, but distinguishes between better and worse desires. Of the latter, he says: ${ }^{20}$

$[\mathrm{S}]$ ome of the unnecessary pleasures and desires are lawless and violent. Perhaps we are all born with them, but they are disciplined by love, and by a combination of reason and the better desires, till in some people they are got rid of altogether, or rendered few and feeble, though in some they retain their numbers and strength.

Plato says of this element ${ }^{21}$ that it shows itself in too many forms for us to be able to describe it in a single word. The mark of it is love of profit or gain. ${ }^{22}$ This element of desire forms the greater part of each man's make-up and is naturally insatiable. It must be prevented from taking its fill of physical pleasures, for otherwise it will get too large and strong to mind its own business and will try to subject and control the other elements which it has no right to do, and so wreck the life of all of them. ${ }^{23}$ Plato says $^{24}$ that the pleasures of a life dedicated to animal instinct are inevitably mixed with pain; they are an empty sham and mere phantoms of true pleasure. This element is incapable of understanding reason or of paying attention to rational argument. ${ }^{25}$

This is how Plato describes the overthrow of reason by appetite in the $\operatorname{Laws}^{26}$ :

[T] he greatest ignorance is when a man hates that which he nevertheless thinks to be good and noble and loves and embraces that which he knows to be unrighteous and evil. This disagreement between the sense of pleasure and the judgement of reason in the soul is, in my opinion, the worst ignorance; and also the greatest because affecting the great mass of the human soul; for the principle which feels pleasure and pain in the individual is like the mass or populace in a state. And when the soul is opposed to knowledge, or opinion, or reason, which are her natural lords, that I call folly, just as in the state, when the multitude refuses to obey their rulers and the laws; or again, in the individual, when fair reasonings have their habitation in the soul and yet do not good, but rather the reverse of good. All these cases I term the worst ignorance, whether in individuals or in states.

How is this turbulent element of desire or appetite to be restrained? Plato does speak of reason as the element of prevention or restraint. ${ }^{27}$ But reason is gentle and does not use force to get its way. Fortunately, reason has an ally in the task of restraining desire, and this ally is the third element in the soul.

The Greek word thumos is an ancient one, going back to Homer, who uses it in the sense of passion, "the rushing and the boiling of the soul". In modern Greek, it usually means anger. As used by Plato, however, this word denotes a range of

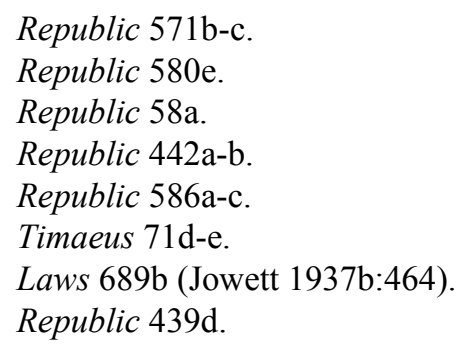


qualities, including will-power, defiance, courage, enterprise, honour, determination and indignation. The word "guts" has a somewhat similar meaning. ${ }^{28}$ Socrates asks. ${ }^{29}$ "Have you not noticed what an irresistible and unbeatable thing high spirits are, giving their possessor a character quite fearless and indomitable in the face of all dangers?" The sole aim of this element is the achievement of success and reputation; its hallmarks are ambition and love of honour. ${ }^{30}$ We shall refer to this element as the element of resolution or the "spirited" element in man. Plato distinguishes this element from reason by saying: "You can see it in children, who are full of spirit as soon as they are born; but some never seem to acquire any degree of reason, and most of them only at a late stage."

This third element, unless corrupted by bad upbringing, is the natural servant and ally of reason. ${ }^{32}$ Thus, says Plato ${ }^{33}$, we often see instances of people whose desires are trying to force them to do something that reason disapproves of. In this struggle, resolution, if it does intervene at all, always intervenes on the side of reason, never on the side of desire.

The true function of this spirited element, then, is to serve reason and always to follow the directions of reason in restraining the appetites. When this element forgets its alliance with reason, trouble beckons: according to Plato ${ }^{34}$, when a man seeks his fill of honour or success or ambition without sense or reason, the desire for honour and success leads to envy and violence, while ambition leads to discontent.

Thus it is reason, the golden principle, which ought always to rule man, having the wisdom and foresight to act for the whole, and the element of resolution ought always to obey and support it. ${ }^{35}$ According to Plato ${ }^{36}$, these two elements are the best defence that mind and body have against external enemies. One of them, reason, will deliberate quietly, while the other will fight under the orders of its superior and provide the courage to carry its decisions into effect.

It was noted earlier ${ }^{37}$ that the three elements, while they are present in every soul, manifest to different degrees in different individuals. Thus Plato recognises ${ }^{38}$ three basic types of person, according to whether they are lovers of knowledge, of honour, or of profit.

28 Lee 1987:125. The same writer (at 208) describes this element as self-regard, self-respect, and as our concern for our reputation and good name. For other descriptions, see Bloom 1991:348f; Guthrie 1962:112-3. Among the Definitions attributed to the work of the members of the Platonic Academy during the fourth century BC, is this one of thumos (Hutchinson 1977:1685): "forceful impulse of the non-rational part of the soul, without being ordered by reasoning ...".

Republic 375a.

Republic 581a.

Republic 441b.

Republic 441a.

Republic 440b.

Republic 586c-d.

Republic 441e.

Republic 442b.

Text to note 10 above.

Republic 581c. 
The three elements are distinct, each having its own nature and function. ${ }^{39}$ This fact, however, should not lead us into the error of concluding that the soul is tripartite, capable of being destroyed by being broken up into parts. ${ }^{40}$

In the Timaeus ${ }^{41}$, Plato paints a vivid picture of the three elements: reason is located in the head, resolution in the breast (that is, in the heart) and appetite in the belly. He describes how the Creator made reason, the divine and immortal principle of soul, with his own hands. The subordinate gods, it is said, then took over this principle from the Creator, encased it in the globe of the skull, and added to it the mortal elements of the soul, namely resolution and desire.

In Plato's description, these gods did not wish to pollute the divine element of reason with mortal feelings any more than was absolutely necessary. Thus they located the two mortal elements in a separate part of the body. They constructed the neck as a kind of isthmus and boundary between head and breast to keep the mortal elements apart from reason. And since, of the two mortal elements, one (resolution) is better than the other (desire) ${ }^{42}$, they divided the hollow of the trunk by inserting the midriff as a partition between them.

The gods located the spirited element of the soul, which is the seat of courage, passion and ambition, nearer the head, between midriff and neck; there it would be well placed to listen to the commands of reason and to combine with it in forcibly restraining the appetites when they refuse to obey the word of command from the citadel.

Finally, they located the appetite for food, drink and other natural needs of the body between the midriff and the region of the navel; there they secured appetite like a wild beast which must be fed if mortals are to exist at all. And they put it there in order that it might be as far as possible from the seat of deliberation, and cause the least possible noise and disturbance, thereby leaving reason, the highest part of us, free to deliberate quietly about the welfare of all.

There is a striking similarity, if not a complete identity, between the Platonic teaching on the threefold nature of the soul, and another trinity which we find in the Vedantic philosophy of India. According to the Bhagavad Gita ${ }^{43}$, nature (prakriti in the original Sanskrit) consists of three qualities (gunas). The first of these (sattwa) comprises purity, serenity, intelligence and moral integrity. The second (rajas) includes energy, restlessness, passion, anger and enthusiasm. The third (tamas) has to do with ignorance, inertia and desire for physical satisfaction. The parallels are obvious. Some have argued that the Platonic model is copied from the Vedantic, but they offer little or no evidence to support this claim ${ }^{44}$. Is it not rather the case that

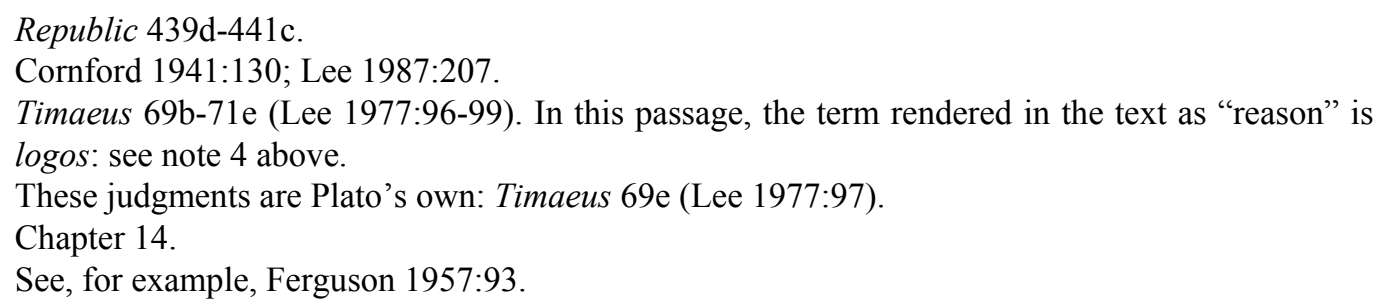


certain fundamental principles of truth exist independently in the philosophical traditions of East and West?

In the Republic, Plato shows that reason is related to the four cardinal virtues of courage, wisdom, temperance and justice. ${ }^{45}$ Thus an individual is courageous when he obeys the orders of reason about what he ought or ought not to fear. Similarly, he is wise by virtue of that small part of him which is in control and issues the orders, knowing as it does what is best for each of the three elements, and for the whole made up of them. Again, he is temperate or self-disciplined when all three elements are in friendly and harmonious agreement, when reason and its subordinates are all agreed that reason should rule and there is no civil war among them. Finally, he is just when each element within him is performing its proper function, whether it is giving or obeying orders. Reason, then, is the thread which runs through and unites these four Platonic or cardinal virtues.

Let us examine the link between reason and justice a little more closely, for it is justice that Plato places at the head of the virtues. ${ }^{46}$ Justice in the individual requires each of the three elements to do its own work, and not to interfere with the work of the others. Thus justice prevails when reason, with the support of its loyal and courageous servant resolution, rules over the appetites. In Plato's own words: ${ }^{47}$

[I]f our desire for gain and our ambition will follow the guidance of knowledge and reason, and choose and pursue only such pleasures as wisdom indicates, the pleasures they achieve will be the truest of which they are capable, because truth is their guide....

Plato, it should be noted, holds here that, in order for justice to prevail, the lower desires should follow the guidance of reason; he does not require that they be altogether suppressed or mortified. ${ }^{48}$ Thus the practical task - no easy one - which Plato assigns to us is to ensure through constant vigilance that desire is subjected to the dominion of reason, supported by its servant, resolution.

A rather mundane example, familiar to this author if not to the reader, may help to make this clear. The desire to eat more food than the body needs can be brought under observation at the critical moment (which could be when one is offered a third helping of one's favourite dessert!). This moment is critical, because it is the moment of choice: either reason, supported by resolution, will restrain desire, the offer will be declined and justice will prevail, or (more commonly in my experience) desire will assert itself, and unjust action will follow. Only alert, detached observation of our inner state at the critical moment will enable us to act reasonably and justly in such cases.

\footnotetext{
$45 \quad$ Republic $442 \mathrm{c}-443 \mathrm{c}$.

46 Plato is hardly consistent in his ranking of the virtues: in Laws 631c, it is wisdom or judgment (phronesis) which takes the first place.

$47 \quad$ Republic $587 \mathrm{~d}-\mathrm{e}$.

48 For Plato's memorable account of the operation of justice in the individual, see Republic 443d-e. In the words of Edman (1927:xlvii): "The just man will be the happy incarnation of the divine order of reason."
} 
How does a person act, in whom each element is performing its proper function? According to Plato ${ }^{49}$, such a person would be the last to embezzle money entrusted to him. It would be unthinkable for him to commit sacrilege or theft, or to betray his friends or his country. He would never break an agreement. He would be the last to commit adultery, dishonour his parents, or be irreligious. We may dismiss this picture as idealistic and unattainable in practice, but Plato does not: for him, this is a just and reasonable condition, the natural condition of man.

Again, it is reason which ought to sustain us in times of grief. A wise man who loses his son or anything dear to him will bear the misfortune more equably than other people; while his sorrow prompts him to give way to grief, reason and principle demand restraint. We must, says Plato ${ }^{50}$, learn not to cling to our hurts and waste our time crying, like children who've bumped themselves, but to train our mind to cure our ills and rectify our lapses as soon as it can. The highest part of us is ready to follow this injunction. The other part of us, which remembers our sufferings and is never tired of bemoaning them may, according to Plato ${ }^{51}$, be called irrational, lazy and inclined to cowardice.

We have now considered what Plato says about the relation of reason to law, and the relation of reason to justice. Plato also considers the relation of reason to knowledge ${ }^{52}$. Knowledge, he says, is true opinion, backed up by reason or rational explanation. Reason, therefore, is the ingredient which transforms true opinion into knowledge.

Can education help to bring the spirited element under the command of reason, thereby enabling reason to rule the soul? Plato's answer to this question is an emphatic "yes". He says: ${ }^{53}$

[T] he united influence of music [mousikē] and gymnastic [gumnastikē] will bring those elements into accord, ... sustaining the reason with noble words and lessons, and moderating and soothing and civilizing the spirited element by harmony and rhythm.

There is no English equivalent for the Greek word mousike , which embraces a great deal more than merely music. Mousike is the sphere of the Muses, of whom there are nine, presiding between them over all the arts, literary, graphic, musical and even intellectual. $^{54}$

Plato insists that a balance be struck between the mental and physical branches of education: the one should not predominate at the expense of the other. ${ }^{55}$ He says: ${ }^{56}$

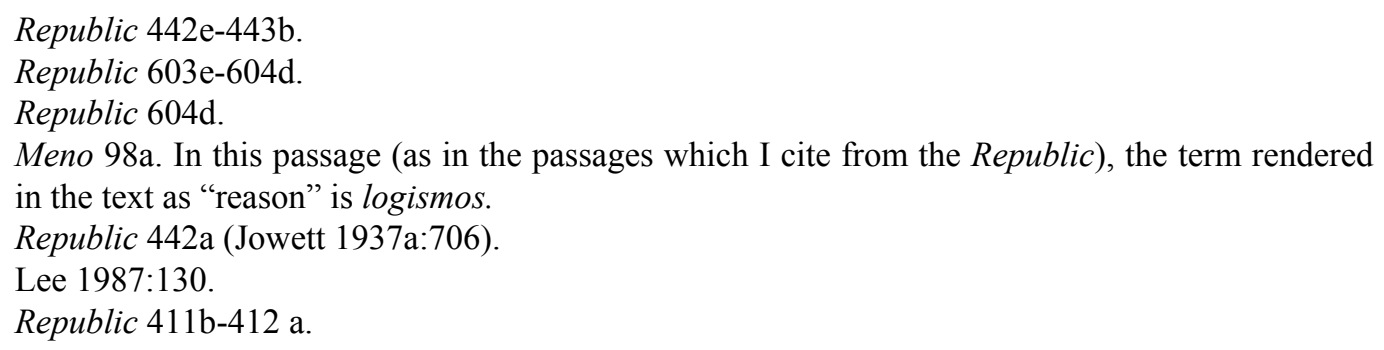


[T]hese two branches of education seem to have been given by some god to man to train these two parts of us - the one to train our philosophic part, the other our energy and initiative. They are not intended the one to train body, the other mind, except incidentally, but to ensure a proper harmony between energy and initiative on the one hand, and reason on the other, by tuning each to the right pitch ... And so we may ... assert that anyone who can produce the perfect blend of the physical and intellectual sides of education and apply them to the training of character, is producing music and harmony of far more importance than any mere musician tuning strings.

When these two elements, the rational and the spirited, have been thus educated to their proper function, they must be put in charge of appetite. ${ }^{57}$

Plato's views on the nature and operation of reason within the individual have now been considered. But what is the source of reason in man? The highest attainment open to man is knowledge of what Plato terms the form or "idea" of "the Good" (agathon). ${ }^{58}$ If we are ignorant of this, the rest of our knowledge, however perfect, is inadequate. In his famous allegory of the cave, Plato ${ }^{59}$ describes "the Good" as:

... the universal author of all things beautiful and right, the parent of light ... in this visible world, and the immediate source of reason and truth in the intellectual world; and ... this is the power upon which he who would act rationally either in public or private life must have his eye fixed.

Not only does reason originate in "the Good", but it is also the sole means by which we may discover "the Good". In his treatment of dialectic, Plato says: ${ }^{60}$

[W] hen a person starts on the discovery of the absolute by the light of reason only, without any assistance of sense, and perseveres until by pure intelligence he arrives at the perception of the absolute Good, he at last finds himself at the summit of the intellectual realm....

Let us now leave the individual and turn to the larger picture: What is the function of reason in the community and in the state? In the Philebus ${ }^{61}$, Socrates puts the question as follows:

Republic 411e-412 a.

Republic 442a.

Republic 505a.

Republic 517c (Jowett 1937a:776). In Timaeus 28b (Lee 1977:40-41), "the Good" is described as the eternally unchanging.

60 Republic 532a-b (Jowett 1937a:791-2). See also Timaeus 28a.

${ }^{61}$ Philebus 28c-e (Frede 1977:416-7). In this passage, the term rendered in the text as "reason" is nous: see note 4 above. 
Are the universe and the whole world order ruled by unreason and irregularity, as chance would have it, or are they not rather, as our forebears taught us, governed by reason and by the order of a wonderful intelligence?

Protarchus answers:

The only account that can do justice to the wonderful spectacle presented by the cosmic order of sun, moon and stars and the revolution of the whole heaven, is that reason arranges it all ...

Socrates affirms ${ }^{62}$ that reason is indeed the cause which orders and co-ordinates the years and seasons. He adds that, in the unanimous verdict of the wise, reason is our king, ruling over both heaven and earth. And in the Timaeus, Plato holds that the world is the fairest of all things that have come into being, and that the creator is the best of causes. ${ }^{63}$ That being so, the world must have been constructed on the pattern of what is apprehensible by reason and understanding, and of what is eternally unchanging.

Plato has much to say about the place of reason in the political, social and economic affairs of humanity. He finds an exact analogy between the individual and the state. In each of us, he says ${ }^{64}$, there are the same three elements which exist in the state. These elements originate in the individual, and pass from the individual into the state, for there is nowhere else for them to come from ${ }^{65}$. It follows that, if we seek peace, harmony and stability in our societies, we have to start (although we cannot stop) with the individual; we must, in short, begin by bringing order to our own inner being. Yet we persist in the belief that our political leaders are somehow to blame for our woes. We deplore the dishonesty and misconduct of those in power, but forget that only by cultivating reason within ourselves will we promote reasonable government in our state.

Corresponding to the elements of reason, resolution and desire in the individual are three key functions in the state. ${ }^{66}$ They are, respectively, the deliberative and governing function, performed by the social class of rulers (or legislators); the executive function, entrusted to the class of auxiliaries (or warriors); and the productive function, performed by the class of businessmen (or traders). The rulers and auxiliaries together are called the guardians of the state ${ }^{67}$. The auxiliaries are to be like watchdogs obeying the rulers, who are the shepherds of the community. ${ }^{68}$ In the key passage from the Laws considered earlier, Plato touches on the operation of reason in the state. ${ }^{69}$

$62 \quad$ Philebus 30c-e (Frede 1977:418).

63 Timaeus 29a-b (Lee 1977:41-42). In this passage, the term rendered in the text as "reason" is logos: see note 4 above.

64 Republic $435 \mathrm{~b}$.

65 Republic 435e.

66 Republic $412 \mathrm{~b}$ ff.

67 Republic 412-421.

68 Republic 440d-e.

69 Laws 645b-c, and text to note 5. 
Again, there is a striking resemblance between this Platonic model of the state and the class structure of ancient India: there the Brahmins, the priest-rulers, stand for sattwa, intelligence and moral integrity. The kshattriyas, soldiers and administrators, represent rajas, the energetic principle. The vaishyas, producers and traders, represent tamas, the desire for physical satisfaction. ${ }^{70}$

Justice in the state, according to Socrates ${ }^{71}$, requires that the three key functions be kept distinct and be rightly performed. When, however, one class usurps or encroaches upon the function of another, disharmony and injustice prevail. ${ }^{72}$ The media remind us constantly that such disharmony is rife in our age.

Plato's philosophy is summed up in the life of reason. Reason is the perception of the realm of absolute truth. The sense organs grasp only the passing and the concrete; the realm of principles and standards is accessible to the true light of reason alone. The good life is the reasonable life. In our days, philosophy has become a technical subject, the exercise of intellectual curiosity for its own sake. But for Plato, philosophy meant also a way of life : a philosopher is one whose soul is governed by reason.

Here, to conclude with, is a memorable passage from the Timaeus: ${ }^{73}$

We should think of the most authoritative part of our soul as a guardian spirit given by God, living in the summit of the body, which can properly be said to lift us from the earth towards our home in heaven; for we are creatures, not of earth but of heaven, where the soul was first born, and our divine part attaches us by the head to heaven, like a plant by its roots, and keeps our body upright. If therefore, a man's attention and effort is centred on appetite and ambition, all his thoughts are bound to be mortal ... But a man who has given his heart to learning and true wisdom, and exercised that part of himself, is surely bound, if he attains to truth, to have immortal and divine thoughts, and cannot fail to achieve immortality as fully as is permitted to human nature; and because he has always served the divine element in himself and kept his guardian spirit in good order, he must be happy above all men.

Reason, then, as Plato conceives it, is more than a cord, more even than a golden cord: it is our very lifeline.

\section{BIBLIOGRAPHY}

Bloom, A (trans) 1991. The Republic of Plato. New York: Simon \& Schuster.

Bury, R G (trans) 1926. Plato: Laws books I-VI. Cambridge, Massachusetts: Harvard UP.

Cooper, J M (ed) 1977. Plato: Complete Works. Indianapolis: Hackett Publishing Company.

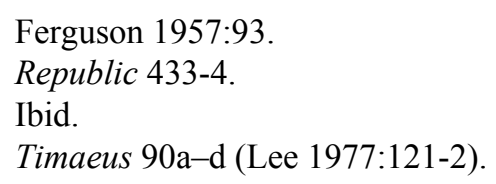


Cornford, F M (trans) 1941. The Republic of Plato. London : Oxford University Press.

D’Entréves, A P (trans) 1951 [1952]. Natural Law: an introduction to legal philosophy. Reprint. London: Hutchinson University Library.

Desjardins, $\mathrm{R}$ 1990. The rational enterprise. Albany:

Dixsout, M 1999. What is it Plato calls "thinking"? Proceedings of the Boston Area Colloquium in Ancient Philosophy (BACAP) 13:1-27.

Edman, I 1927. In Edman, I (ed) The Works of Plato. New York: The Modern Library.

Ferguson, J 1957. In Ferguson, J (ed) Plato: Republic Book X. London: Methuen \& Co Ltd.

Field, G C 1967. Plato and his contemporaries. $3^{\text {rd }}$ ed. London: Methuen \& Co Ltd.

Frede, D (trans) 1977. In Cooper 1977: 398-456.

Frede, M \& Striker, G (ed) 1996. Rationality in Greek thought. New York/Oxford: Oxford University Press.

Guthrie, W K C 1962 [1950]. The Greek philosophers from Thales to Aristotle. Reprint. London: Methuen \& Co Ltd.

Hendrix, J 2000. The world soul and the good in the construction of an ethical rationality in Plato's Laws. Skepsis 11:99-108.

Howard, P K 1996. The death of common sense. New York: Warner Books.

Hutchinson, D S (trans) 1977. In Cooper 1977:1677-1686.

Jowett, B (trans) 1937 [1892]a. The dialogues of Plato. Vol.1. $3^{\text {rd }}$ ed. Reprint. New York: Random House.

Jowett, R (trans) 1937 [1892]b. The dialogues of Plato. Vol 2. $3^{\text {rd }}$ ed. Reprint. New York: Random House.

Lee, D (trans) 1977 [1965]. Plato: Timaeus and Critias. Reprint. London: Penguin Books.

Lee, D (trans) 1987 [1955]. Plato: The Republic. $2^{\text {nd }}$ ed. Reprint. London: Penguin Books.

Miller Jr, F D 1997. Plato on the parts of the soul. In Van Ophuijsen (ed), Plato and Platonism, 84-101. Washington DC:

Penner, T E 1992. In Kraut (ed) The Cambridge companion to Plato. Cambridge: Cambridge University Press.

Rowe, C J 1984. Plato. Cambridge: Cambridge University Press.

Saunders, T J (Trans) 1975 [1970]. Plato: The Laws. Reprint. London: Penguin Books.

Schmid, W T 1998. Plato's Charmides and the Socratic ideal of rationality. Albany:

Suzanne, B F 1996. Plato and his dialogues. Essay on the website: http://eawc.evansville,edu/essays/suzanne.html, 1-16. 